\title{
Ethnologies
}

\section{Cree Narratives: Expressing the Personal Meaning of Events. By Richard J. Preston. (Montréal- Ithaca, McGill-Queen's University Press, 2002. Pp. xvii + 285, ISBN 0773523626)}

\section{Anna Hoefnagels}

Volume 26, numéro 1, 2004

Littératie

Literacy

URI : https://id.erudit.org/iderudit/013352ar

DOI : https://doi.org/10.7202/013352ar

Aller au sommaire du numéro

Éditeur(s)

Association Canadienne d'Ethnologie et de Folklore

ISSN

1481-5974 (imprimé)

1708-0401 (numérique)

Découvrir la revue

Citer ce compte rendu

Hoefnagels, A. (2004). Compte rendu de [Cree Narratives: Expressing the Personal Meaning of Events. By Richard J. Preston. (Montréal- Ithaca, McGill-Queen’s University Press, 2002. Pp. xvii + 285, ISBN 0773523626)].

Ethnologies, 26(1), 248-250. https://doi.org/10.7202/013352ar d'utilisation que vous pouvez consulter en ligne.

https://apropos.erudit.org/fr/usagers/politique-dutilisation/ 
Cree Narratives: Expressing the Personal Meaning of Events. By Richard J. Preston. (Montréal- Ithaca, McGill-Queen's University Press, 2002. Pp. xvii + 285, ISBN 0773523626)

Originally published in 1975 as part of the National Museum of Man Mercury Series of the National Museums of Canada, Cree Narrative: Expressing the Personal Meaning of Events is an excellent account of various aspects of traditional Cree life in Northern Québec. Written by Richard J. Preston, Professor Emeritus of Anthropology at MacMaster University, this book is based primarily on field research in the summers from 1965 to 1969 in Waskaganish (Rupert's House, QC). This monograph offers captivating detail about the historic nomadic patterns of the Cree in their hunt for food, and aspects of Cree spirituality, particularly regarding the Mistabeo (non-human spirits that assist in the hunt and survival of the Cree).

Stressing the importance and vitality of oral tradition and storytelling in Cree culture, this book is peppered with English translations of narratives from Cree informants, which serve as the basis of Preston's analysis of Cree culture. The book is organized around various themes ranging from conjuring to relationships and hunting, based on narratives generated from the Cree. Preston emphasizes the importance of narration to understanding Cree culture by saying: "Cree individuals often do not convey explanation in the form of simple, single facts, preferring instead to converse about events in a narrative form. The context of narration (as contrasted with isolated facts) functions to convey to the hearer a whole and precise perception, sometimes almost a visual image, within the appropriate, inherent context. By conveying facts within their context, then, the Cree attempt a precise understanding or, on the negative side, prevent distorted or incomplete understanding" (69).

Preston's analyses of Cree culture are very insightful and interesting; however, aside from introductory comments explaining his methodology, he never accounts for, or acknowledges, feedback from the Cree themselves. Instead, his account of Cree traditional life is based mainly on the narratives offered to him by John Blackned, translated into English by Willy Weistance. Not to question the legitimacy of Blackned's accounts, one must question if it is sound ethnographic research if there is primarily one informant serving as the representative of an entire culture. As a reader I wonder if other Cree in the James Bay region might have other narratives to offer, and I also 
wonder how other Cree would respond to Preston's analyses drawn primarily from a single source.

Preston rationalizes this new edition by indicating that modern anthropological methods and theory encourage the anthropologist to focus on narration and languages as a means of learning about a culture. However, one must question the anthropological privilege that assumes that a "learner" or "student" of a culture can truly understand and/or represent the culture of "another." This was a criticism of the first edition (Tanner: 192) and remains a concern for the present reviewer. Furthermore, the new prefatory material of the second edition, written by Preston, highlights his belief that this text, in its 1975 version was setting the trend for later anthropologists such as Robin Ridington and Julie Cruikshank in the reliance on narratives for constructing cultural knowledge. However, unlike these later authors who engage and collaborate with their informants, there is little evidence of collaboration in Preston's work. Although Cree Narrative may have been a forwardlooking research publication in 1975, it is now an account clearly derived from older-style ethnography.

Despite its strengths as a beautiful, well-written and fascinating text, it is disappointing for readers that there are few textual differences in the main body of the book in comparison with the first edition. Indeed, the second edition of this text is primarily cosmetic, with the addition of three new sections that are not integrated with the rest of the monograph. Preston does not demonstrate his engagement with new research on the Cree, nor his familiarity with new issues and trends in anthropology. Areas for future study that Preston highlights in the first edition (e.g. the meaning of the tuft on the trees used to construct the shaking tent [82]; human relationships with the animal world [167]) are not developed or answered in the second edition; rather the text in the second edition is exactly duplicated from the first, with additional references added in square brackets behind the original endnotes at the back of the book. Despite its publication in 2002, the second edition of Cree Narratives does not engage with issues that have become mainstays in anthropological research since the first edition, most notably in terms of gender conventions and restrictions. This text focuses solely on the life patterns and relationships with nature as experienced by male Cree. Although Preston occasionally indicates restrictions around women's participation in cultural activities (such as the shaking tent, or the hunt), very little information is addressed or developed on 
the roles of women in Cree culture and their relationship with nature, and, if those issues do get raised, they are usually highlighted as an area for further investigation. At this point in the history of anthropological theory and research, women's roles in culture should not be dismissed and undeveloped.

Preston invokes few references to other research on the Cree since the first edition, augmenting his original bibliography with articles written by him and few other researchers. However, at various points he acknowledges his ignorance, stating, in a footnote, for example: "I prefer to skirt this issue until I am more adequately prepared to detail my position." Unfortunately, he does not incorporate his developed position into the text of the second edition; rather he documents a number of papers that he has written on the subject (270). For the reader of the new edition, almost 30 years after the first edition, it is disappointing that new information is not incorporated into the main body of the text.

Despite criticisms of the second edition of Cree Narratives, this book offers anthropologists informative and interesting insight into some of the historic practices of the eastern Cree in Canada, as well as historic ethnographic practices of anthropologists researching and writing in the 1960s and 1970s. It is a very well written and throughtful text, which is a pleasure to read.

Anna Hoefnagels Augustana University College

Camrose, Alberta

\section{References}

Preston, Richard J. 1975. Cree Narrative: Expressing the Personal Meanings of Events. Ottawa: National Museum of Man Mercury Series, Canadian Ethnology Service Paper no 30.

Tanner, Adrian. 1977. "Book review of Cree Narrative". Arctic Journal of the Arctic Institute of North America 30 (3): 192-193. 